\title{
Uterine luminal proteins at the time of implantation in rats
}

\author{
M. A. H. Surani \\ Physiological Laboratory, University of Cambridge, Cambridge CB2 3EG, U.K.
}

\begin{abstract}
Summary. Changes in rat uterine luminal proteins were analysed during pregnancy and after ovariectomy on Day 3 of pregnancy plus daily administration of progesterone, when delay of implantation is imposed. Total protein levels reached a peak level on Day 5 of pregnancy, the day of implantation, in the intact but not the ovariectomized females. Qualitative analyses of protein-SDS complexes showed an increase in a protein of molecular weight of approximately 70,000 and others of higher molecular weight during pregnancy, but in ovariectomized females the proteins of higher molecular weight were virtually undetectable by Day 10. The entry of blastocysts into quiescence after ovariectomy appears to be an adaptation by the embryos to suboptimal uterine luminal conditions.
\end{abstract}

\section{Introduction}

Characteristic changes in uterine luminal proteins are detected after administration of steroids to ovariectomized rats (Surani, 1975a) and during pregnancy in mice (Gore-Langton \& Surani, 1976). These changes appear to be important for the regulation of cell proliferation and metabolism of the preimplantation blastocyst. Blastocysts exist in either the proliferative or quiescent state. The former state is found on Day 5 of pregnancy in the rat when the embryonic cell proliferation rate and metabolism is at a peak level (Webb \& Surani, 1975; Surani, 1975b). Embryonic quiescence occurs during lactation or in females ovariectomized on Day 3 and given progesterone, when embryonic mitotic activity ceases (Surani, 1975b) and cell metabolism declines to a basal level; resumption of metabolic activity and implantation follow when such females are injected with oestradiol (Weitlauf, 1974a). There are several interpretations of the way in which steroids may act to release embryos from quiescence (McLaren, 1973).

As an extension of a previous investigation (Surani, 1975a), the present study was of the changes of uterine luminal proteins in pregnant rats and in rats ovariectomized on Day 3 of pregnancy and treated with progesterone to induce delay of implantation.

\section{Materials and Methods}

Animals. Female Wistar rats weighing $180 \mathrm{~g}$ were housed 3 per cage and mated. The day on which spermatozoa were detected in the vaginal smear was taken as Day 1 of pregnancy, and females were killed at $\mathbf{1 2 . 0 0}$ hours on each day thereafter up to Day 5 of pregnancy. Some females were ovariectomized on Day 3 of pregnancy and given a daily s.c. injection of $4.0 \mathrm{mg}$ progesterone in $0.2 \mathrm{ml}$ arachis oil. These females were killed between Days 4 and 30 to study quantitative and qualitative changes in the intraluminal proteins during the period when embryos enter into quiescence.

Collection of uterine intraluminal extracts and disc gel electrophoresis. Each uterine horn was flushed with $0.1 \mathrm{ml} \mathrm{0.01} \mathrm{M}$-phosphate buffer and the protein-SDS complexes from each animal were analysed on $7 \cdot 5 \%$ polyacrylamide gels as previously described (Surani, 1975a). The gels were scanned using a Joyce Loebl Chromoscan densitometer, protein bands being detected by transmission using a complementary filter of $595 \mathrm{~nm}$.

Total intraluminal protein content in the flushings of the two horns in $0.2 \mathrm{ml} 0.154 \mathrm{M}-\mathrm{NaCl}$ was estimated by the method of Lowry, Rosebrough, Farr \& Randall (1951). 


\section{Results}

Changes in the total intraluminal protein content. As shown in Table 1, the total protein content in pregnant rats was high on Day 1, perhaps because of the presence of leucocytes and breakdown products of spermatozoa or high circulating levels of oestrogen at pro-oestrus, and after a decline rose again on Day 5. The levels did not change markedly on Days 6 and 7 when the material was obtained from animals with ligated uterotubal junctions to prevent the entry of embryos into the uterus. In the ovariectomized females, the protein levels did not increase.

Table 1. Mean \pm S.D. total protein content of the uterine intraluminal contents of pregnant or ovariectomized (Day 3 of pregnancy) rats

\begin{tabular}{cccccc}
\hline $\begin{array}{c}\text { Day of } \\
\text { pregnancy }\end{array}$ & $\begin{array}{c}\text { No. of } \\
\text { animals }\end{array}$ & $\begin{array}{c}\mu \text { Protein/ } \\
\text { rat }\end{array}$ & $\begin{array}{c}\text { Days after } \\
\text { ovariectomy }\end{array}$ & $\begin{array}{c}\text { No. of } \\
\text { animals }\end{array}$ & $\begin{array}{c}\mu g \text { Protein/ } \\
\text { rat }\end{array}$ \\
\hline 1 & 9 & $100 \cdot 05 \pm 9 \cdot 0$ & & & \\
2 & 16 & $41 \cdot 25 \pm 2 \cdot 5$ & & & \\
3 & 12 & $30 \cdot 06 \pm 3 \cdot 1$ & & 15 & $40 \cdot 0 \pm 5 \cdot 0$ \\
4 & 15 & $49 \cdot 70 \pm 5 \cdot 0$ & 4 & 21 & $39 \cdot 9 \pm 8 \cdot 0^{*}$ \\
5 & 16 & $72 \cdot 92 \pm 7 \cdot 6^{*}$ & 5 & 16 & $40 \cdot 0 \pm 6 \cdot 9$ \\
$6 \dagger$ & 9 & $65 \cdot 42 \pm 3 \cdot 2$ & 6 & 11 & $33 \cdot 0 \pm 7 \cdot 1$ \\
$7 \dagger$ & 8 & $60 \cdot 01 \pm 6 \cdot 1$ & 7 & 12 & $30 \cdot 0 \pm 7 \cdot 2$ \\
& & & 8 & 15 & $27 \cdot 1 \pm 9 \cdot 0$ \\
& & & 9 & 11 & $20 \cdot 2 \pm 8 \cdot 3$ \\
\hline
\end{tabular}

\footnotetext{
* Significantly different, $P<0.05$ (Student's $t$ test).

$\dagger$ Animals with ligated uterotubal junctions.
}

Qualitative analysis of proteins. During pregnancy there was a gradual increase in proteins of approximate molecular weight of 70,000 and others of higher molecular weight which became prominent by Day 5 (Pl. 1, Fig. 1), the day of implantation in the rat. In the ovariectomized females the expected increase in the proteins on Day 5 was not detected. The densitometer scans (Text-fig. 1) show that the effects of ovariectomy on the luminal proteins were evident as early as Day 5 (compare P5 with X5) so that the proteins of molecular weight of 70,000 and others of higher molecular weight were quantitatively reduced when compared with those of intact females. By the 10th day, the higher molecular weight proteins were usually absent. By Day 30 there was a further decline in most of the luminal proteins (Pl. 1, Fig. 2). There were no detectable qualitative differences, as shown by analysis on gel columns, in the proteins from spayed females compared with those from pregnant rats apart from the lack of higher molecular weight proteins in the former.

\section{Discussion}

The increase in the protein of molecular weight 70,000 and greater and in the total proteins detected on Day 5 of pregnancy are likely to be oestrogen-dependent since these changes are interrupted when females are ovariectomized on Day 3 and given progesterone alone. When oestradiol is administered to ovariectomized females treated with progesterone alone, proteins are released into the lumen which are similar to those found during pregnancy (Surani, 1975a). The increased protein content in the lumen during pregnancy may be due, at least in part, to the secretion of uterine-specific proteins. Oestradiol is known to cause the synthesis of nonhistone chromosomal proteins in the uterus (Cohen \& Hamilton, 1975) and on Day 5 of pregnancy there is an enhancement of chromatin template activity and new species of RNA (O'Grady et al., 1975) as well as in the synthesis of endometrial soluble proteins (Yochim, 1975).

Embryos at the blastocyst stage depend on exogenous macromolecules for postimplantation changes and the presence of a high molecular weight serum fraction evokes such development in vitro (Spindle \& Pedersen, 1973). The failure of the expected increase in proteins of mol. wt $\geqslant 70,000$ 
PLATE 1

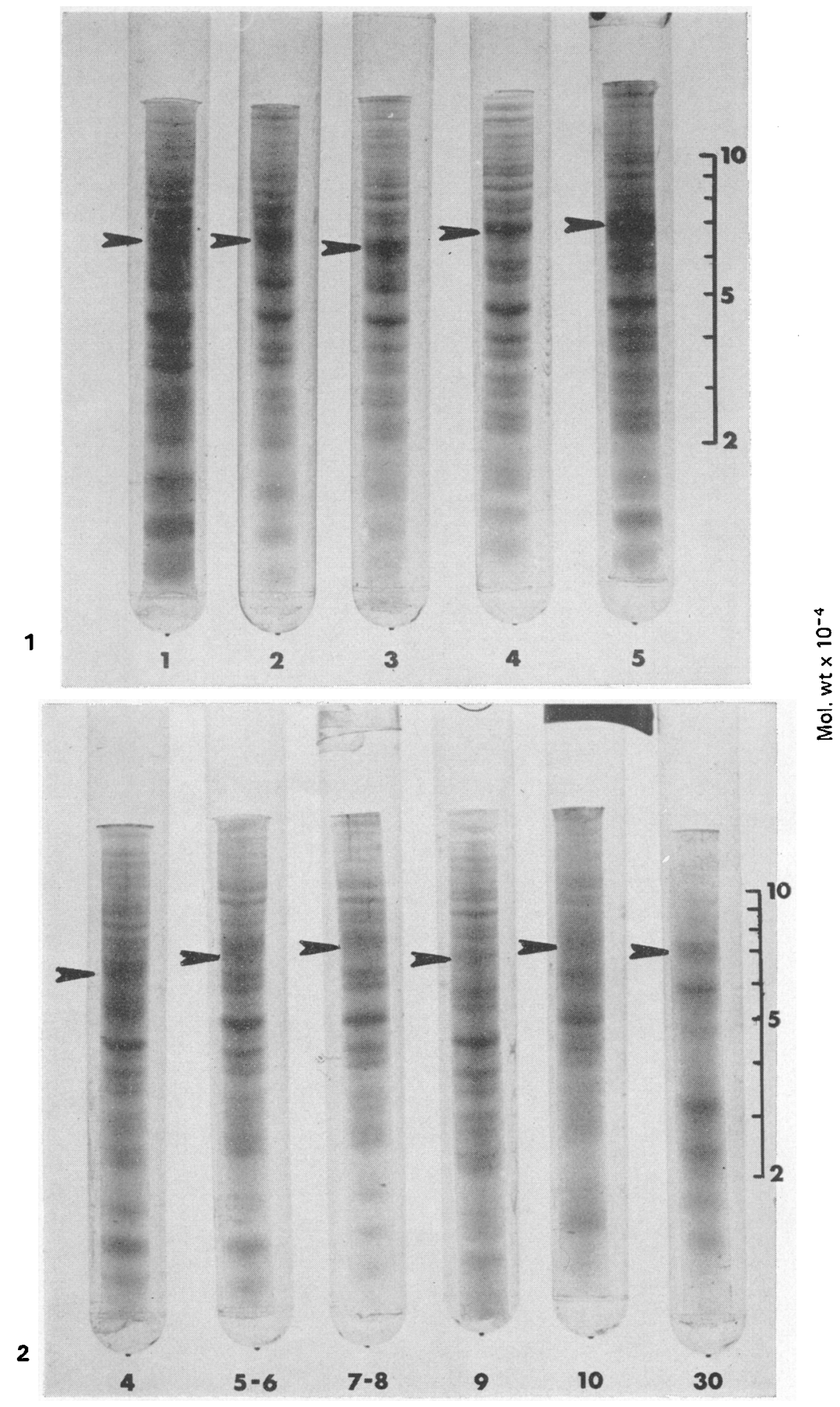

\section{Days}

Separation of protein-SDS complexes of uterine luminal proteins of rats during pregnancy (Fig. 1) compared with those detected after ovariectomy on Day 3 and daily treatment with progesterone (Fig. 2). Note the gradual decline and the absence of higher molecular weight proteins by the 10th day after ovariectomy. The position of protein of approximate molecular weight 70,000 is indicated by the arrow heads. 


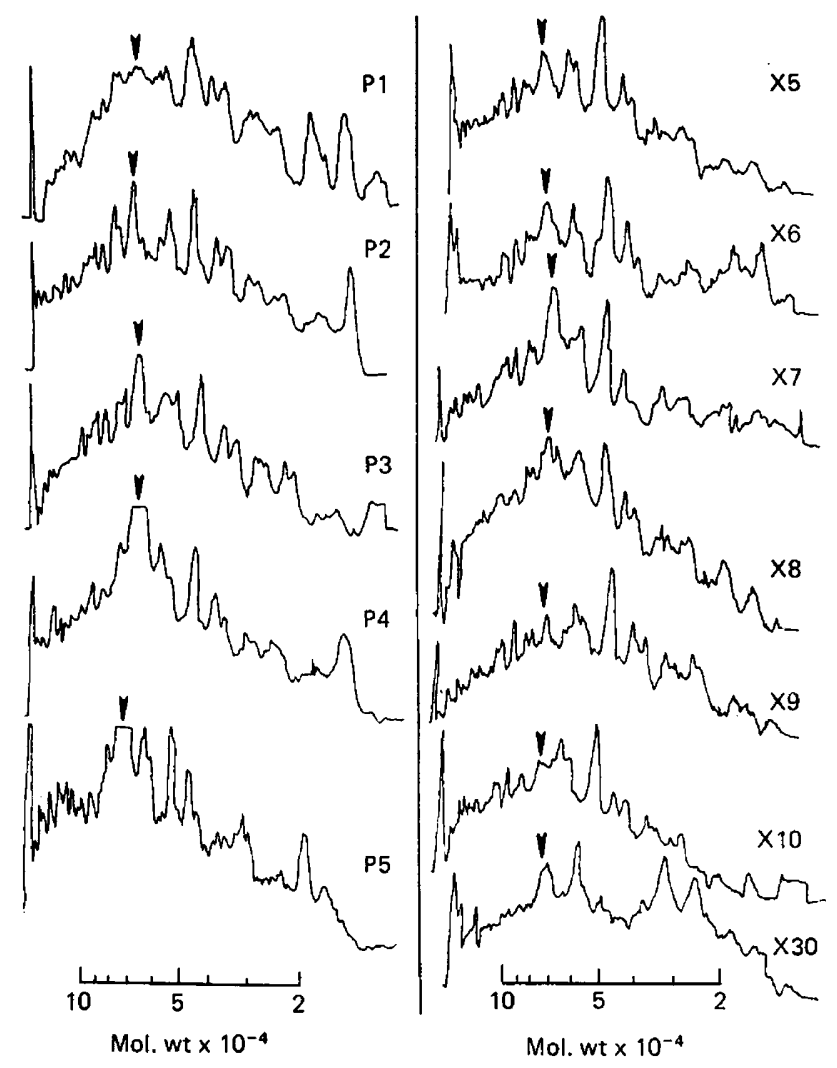

Text-fig. 1. Densitometer scans of the gels shown in Plate 1. Note an increase in the protein band of approximate molecular weight 70,000 (arrow head) and greater during pregnancy (P series) compared with protein profiles after ovariectomy on Day 3 (X series). Compare especially the protein components on Day 5 of pregnancy (P5), the day of implantation, with the protein components present on the 5th day (X5) after ovariectomy on Day 3 of pregnancy.

after ovariectomy will affect blastocyst cell proliferation and metabolism. Consequently, whereas blastocyst cell doubling occurs every $10 \mathrm{hr}$ during pregnancy (Surani, 1975b), this increases to $48 \mathrm{hr}$ in ovariectomized rats on Day 5 (Sanyal \& Meyer, 1972). With the further decline in protein content and the virtual absence of the higher molecular weight proteins by the 10th day, embryonic mitotic activity declines and ceases (Surani, 1975b) and metabolic activity falls to basal levels (McLaren, 1973; Weitlauf, 1974a; Webb \& Surani, 1975). This capacity for adaptation may enable embryos to survive during environmental conditions not conducive for growth or implantation. Similar adaptation by embryos to the uterine environmental conditions may occur in other species, such as the roe deer (Aitken, 1974) and the northern fur seal (Daniel, 1971), in which seasonal delay of implantation occurs. In both these species, intraluminal protein content is very low during embryonic quiescence but increases when implantation resumes. In the northern fur seal, blastocyst cell doubling time increases to 50-60 days during quiescence, and at the time of resumption of metabolic activity and implantation a high molecular weight protein peak appears together with an increase in total macromolecules (Daniel, 1971).

Rat embryos therefore appear to enter into quiescence as a result of adaptation to luminal environmental conditions which are suboptimal, especially with regard to a lack of higher molecular weight proteins. Similar adaptation and entry into quiescence is known in other eukaryotic cells after serum starvation (Hershko, Mammont, Shields \& Tomkins, 1971; Pardee, 1974). This explanation for embryonic quiescence is contrary to the suggestion that the embryos are maintained in 
quiescence by a unique uterine inhibitor(s) acting at the transcriptional level (Psychoyos, 1973; Weitlauf, 1974b). The main evidence for the latter arises from studies showing that when quiescent embryos are explanted in vitro there is a resumption of normal metabolic activity (Bitton-Casimiri, Brun \& Psychoyos, 1976). The stimulation may occur because of the presence of serum and essential ions such as calcium in the medium, and apart from humoral factors, cell-to-cell interactions between the trophoblast and uterine epithelium may be important during adhesion and implantation as well as during quiescence.

The changes in the uterine secretions in the rat and the mouse are characteristic, if subtle, and some proteins produced in the uterine secretions in response to oestrogen could possess high specificity and potency for the enhancement of embryonic metabolism and these therefore need not be present in abundance. The proteins could presumably bind to embryonic surface receptors and could thereby initiate a coordinated intracellular response leading to an increase in RNA, protein and DNA synthesis, preceded perhaps by alterations in the levels of cyclic nucleotides. This would be in keeping with the known action of some macromolecular mitogens (Rudland, Seifert \& Gospodarowicz, 1974). Such increases in the protein synthesis in response to extracellular mitogens may be governed by the recruitment of ribosomes and the resulting translation of pre-existing untranslated mRNA, rather than transcription (Rudland, 1974; Bandman \& Gurney, 1975), because a generalized synthesis of all detectable peptides is observed after re-activation of quiescent embryos (Van Blerkom \& Brockway, 1975). Further determinations on the synthesis and secretion of uterine proteins are needed and then studies of their effects on embryos at the cellular level can be extended.

This work was supported by a grant from the Medical Research Council and the Ford Foundation. I thank Dr R. G. Edwards and Professor C. R. Austin for their criticisms.

\section{References}

AITKEN, R.J. (1974) Delayed implantation in roe deer (Capreolus capreolus). J. Reprod. Fert. 39, 225-233.

Bandman, E. \& GuRney, T. (1975) Differences in the cytoplasmic distribution of newly synthesized poly (A) in serum-stimulated and resting cultures of BALB/c 3T3 cells. Expl Cell Res. 90, 159-168.

Bitton-Casimiri, V., Brun, J.L. \& Psychoyos, A. (1976) Uptake and incorporation of $\left[{ }^{3} \mathrm{H}\right]$ uridine by normal or diapausing rat blastocysts after various periods of culture. J. Reprod. Fert. 46, 447-448.

Cohen, M.E. \& Hamilton, T.H. (1975) Effect of estradiol-17 $\beta$ on the synthesis of specific uterine nonhistone chromosomal proteins. Proc, natn. Acad. Sci. U.S.A. 72, 4346-4350.

DANIEL, J.C., JR (1971) Growth of the preimplantation embryo of the northern fur seal and its correlation with changes in uterine protein. Devl Biol. 26, 316331.

Gore-Langton, R.E. \& SuRANi, M.A.H. (1976) Uterine luminal proteins of mice. J. Reprod. Fert. 46, 271274.

Hershko, A., Mammont, P., Shields, R. \& Tomkins, G.M. (1971) Pleiotypic response. Nature, Lond. 232, 206-211.

Lowry, O.H., Rosebrough, N.J., FARR, A.L. \& RANDALL, R.J. (1951) Protein measurement with Folin phenol reagent. J. biol. Chem. 193, 265-275.

McLaren, A. (1973) Blastocyst Activation. In Regulation of Mammalian Reproduction, pp. 321-328. Eds S. J. Segal, R. Crozier, P. A. Corfman \& P. G. Condliffe. Thomas, Springfield, Illinois.
O'Grady, J.E., Moffat, G.E., McMinn, L., Vass, M.A., O'Hare, A. \& Heald, P.J. (1975) Uterine chromatin template activity during the early stages of pregnancy in the rat. Biochim. biophys. Acta 407, 125-132.

PardeE, A. (1974) A restriction point for control of normal animal cell proliferation. Proc. natn. Acad. Sci. U.S.A. 71, 1286-1290.

Psychoyos, A. (1973) Hormonal control of ovoimplantation. Vitams Horm. 31, 201-256.

RUDLAND, P.S. (1974) Control of translation in cultured cells: continued synthesis and accumulation of messenger RNA in non-dividing culture. Proc. natn. Acad. Sci. U.S.A. 71, 750-754.

Rudland, P.S., Seifert, W. \& Gospodarowicz, D. (1974) Growth control in cultured mouse fibroblasts: induction of the pleiotypic and mitogenic responses by a purified growth factor. Proc. natn. Acad. Sci. U.S.A. 71, 2600-2604.

SANYAL, M.K. \& MEYer, R.K. (1972) Deoxyribonucleic acid synthesis in vitro in normal and delayed nidation preimplantation blastocysts of adult rats. J. Reprod. Fert. 29, 439-442.

Spindle, A.I. \& Pedersen, R. (1973) Hatching, attachment and outgrowth of mouse blastocysts in vitro: fixed nitrogen requirements. J. exp. Zool. 186, 305318.

SURANI, M.A.H. (1975a) Hormonal regulation of proteins in the uterine secretion of ovariectomized rats and the implications for implantation and embryonic diapause. J. Reprod. Fert. 43,411-417. 
SURAN, M.A.H. (1975b) Zona pellucida denudation, blastocyst proliferation and attachment in the rat. J. Embryol. exp. Morph. 33, 343-353.

Van Blerkom, J. \& Brockway, G.O. (1975) Patterns of protein synthesis in pre-implantation mouse embryos. II. During release from facultative delayed implantation. Devl Biol. 46, 446-451.

WeBb, F.T.G. \& SURANI, M.A.H. (1975) Influence of environment on blastocyst proliferation, differentiation and implantation. In Regulation of Growth and
Differentiated Function in Eukaryotic Cells, pp. 519522. Ed. G.P. Talwar. Raven Press, New York.

WeITLAUT, H.M. (1974a) Metabolic changes in the blastocysts of mice and rats during delayed implantation. J. Reprod. Fert. 39, 213-224.

WerrzaUr, H.M. (1974b) Effect of actinomycin D on protein synthesis by delayed implanting mouse embryos in vitro. J. exp. Zool. 189, 197-202.

YoснIм, J.M. (1975) Development of the progestational uterus-metabolic aspects. Biol. Reprod. 12, 106-133.

Received 9 March 1976 